\title{
Pengaruh Model Pembelajaran Think Pair Share Berbantuan Media TTS terhadap Kompetensi Pengetahuan IPA
}

\author{
*I Kadek Tony Suantara1, Ni Nyoman Ganing², I Gusti Agung Ayu Wulandari
}

1,2,3 Jurusan Pendidikan Dasar, Universitas Pendidikan Ganesha, Singaraja, Indonesia

A R T I C L E I N F O

Article history:

Received in revised form

Accepted 10 October 2019

Available online 27

November 2019

Kata Kunci:

think pair share,

pengetahuan IPA

Keywords:

think pair share,

competency
Received 15 August 2019

20 September 2019

\begin{abstract}
A B S T R A K
Penelitian ini bertujuan untuk mengetahui perbedaan yang signifikan kompetensi pengetahuan IPA antara kelompok siswa yang mengikuti pembelajaran menggunakan model pembelajaran TPS berbantuan media permainan TTS dengan kelompok siswa yang mengikuti pembelajaran konvensional pada siswa kelas $\mathrm{V} S \mathrm{SD}$. Jenis penelitian ini adalah penelitian eksperimen semu menggunakan desain nonequivalent posttest only control group design. Populasi penelitian ini adalah seluruh siswa kelas V SD. Sampel penelitian ini adalah SDN 4 jumlah 39 siswa sebagai kelompok eksperimen dan SDN 3 dengan jumlah 35 siswa sebagai kelas kontrol. Pemilihan sampel dilakukan dengan teknik random sampling. Pengumpulan data dalam penelitian ini dilakukan menggunakan metode tes jenis objektif dalam bentuk pilihan ganda biasa. Data yang telah terkumpul dianalisis menggunakan metode analisis statistik inferensial (uji-t). Berdasarkan hasil analisis
\end{abstract} data, diperoleh thit $=3,82$ dengan taraf signifikansi $5 \%$ dan $\mathrm{dk}=72$ diperoleh $\mathrm{t}_{\mathrm{tab}}=2,00$, $\mathrm{t}_{\text {hit }}=3,82>$ 2,00 . Perhitungan nilai rata-rata siswa yang mengikuti pembelajaran Kooperatif tipe TPS berbantuan media permainan TTS $(\bar{X}=82,69)>$ dengan siswa yang dibelajarkan dengan model konvensional $(\bar{X}$ $=73,94)$. dengan demikian dapat disimpulkan bahwa penerapan model pembelajaran Kooperatif tipe TPS berbantuan media permainan TTS berpengaruh terhadap kompetensi pengetahuan IPA siswa kelas V SD.

\begin{abstract}
A B S T R A C T
This research has a purpose to know the significant difference of science competency between students taught by learning model TPS combined with TTS game with students taught by conventional technique for 5 grades students at SD Gugus Kompyang Sujana Denpasar Utara year 2018/2019. This is a quasi-experimental research using non-equivalent posttest only control group design. The population was all 5 grades students at SD Gugus Kompyang Sujana Denpasar Utara year 2018/2019. The sample took SDN 4 Peguyangan which consist of 39 students as experimental group and SDN 3 Tinja which consist of 35 students as control group. Random sampling technique was used in choosing the sample. The data was collected by objective test in form of multiple choices. The collected data was analyzed by using inferential statistic ( $t$-test). Based on the result of the analysis, it was obtained that $t_{\text {calculated }}=3,82$ with significance level $5 \%$ and $d k=72$ showed that $t_{\text {table }}=2,00$. So, $t_{\text {calculated }}=3,82>2,00$. The mean score of students taught by TPS combined with TTS game $(\underline{X}=$ $82,69)$ was better than students taught by conventional technique $(\underline{X}=73,94)$. It is concluded that learning model TPS combined with TTS game gave significant effect on science competency of 5 grades students at SD N Gugus Kompyang Sujana Denpasar Utara year 2018/2019.
\end{abstract}

\section{Pendahuluan}

Pendidikan merupakan salah satu faktor yang sangat penting dalam pembangunan suatu negara. Pendidikan memiliki peran yang sangat penting dalam mencerdaskan kehidupan bangsa. Peningkatan mutu pendidikan sangat berpengaruh terhadap kualitas sumber daya manusia, (Salahuddin et al., 2018) Suatu negara dikatakan maju atau tidaknya dapat dilihat dari seberapa tinggi kualitas pendidikan yang

Copyright (®) Universitas Pendidikan Ganesha. All rights reserved. 
masih ada di negara tersebut. Pendidikan mempunyai peranan yang sangat menentukan perkembangan dan perwujudan diri individu, terutama bagi pembangunan bangsa dan negara, (Sari \& Septiasari, 2016) Melalui pendidikan dapat dibentuk peradaban bangsa yang cerdas dan bermartabat. Pendidikan berperan dalam membentuk siswa menjadi manusia yang beriman, bertakwa kepada Tuhan Yang Maha Esa, berakhlak mulia, mandiri, berilmu, bertanggung jawab, taat hukum dan menjadi warga negara yang demokratis. Untuk menghujudkan hal tersebut maka tidak terlepas dari proses pembelajran dan muatan pelajaran yang diberikan.

Mata pelajaran yang diajarkan di Sekolah dasar yaitu IPA, IPS, Matematika, Bahasa Indonesia, Pendidikan Kewarganegaraan, Pendidikan Agama, Budi Pekerti, Pendidikan Bahasa Daerah, Seni Budaya dan keterampilan (SBK) dan Penjaskes. IPA atau Ilmu Pengetahuan Alam merupakan salah satu mata pelajaran yang wajib dipelajari, (I Made Yudha Pranata, I Wayan Suwatra, 2017) IPA sangat diperlukan baik untuk kehidupan sehari hari maupun dalam menghadapi kemajuan IPTEK (Ilmu Pengetahuan Dan Teknologi) sehingga IPA perlu dibekali kepada setiap peserta didik sejak SD. IPA berkaitan dengan segala pengetahuan yang berupa fakta-fakta tetapi juga proses penemuan. (Abdilah, 2018) menyatakan "Ilmu Pengetahuan Alam (IPA) berkaitan dengan cara mencari tahu tentang alam secara sistematis, sehingga IPA bukan hanya penguasaan kumpulan pengetahuan yang berupa fakta-fakta, konsep-konsep, atau prinsip-prinsip saja tetapi juga merupakan suatu proses penemuan".

Kompetensi Pengetahuan IPA diperoleh secara optimal, ketika siswa mampu mengolah dan memahami materi pembelajaran yang diberikan. Hal tersebut tentu tidak terlepas dari peran seorang guru yang dituntut untuk melakukan pembaharuan-pembaharuan. Pendidikan dalam mengelola kelas secara kondusif yang dapat membantu siswa dalam mencapai kompetensi pengetahuan IPA yang optimal. Sejalan dengan pendapat (Samatowa, 2010) bahwa kompetensi pengetahuan ipa tidak semata mata bergantung pada apa yang dijelaskan guru, melainkan apa yang diperoleh anak dan bagaimana anak mengolah informasi tersebut berdasarkan pemahaman yang telah dimiliki sebelumnya. Peran guru dan siswa harus beriringan dan jika itu terjadi maka akan berdampak pada ketercapaian kompetensi pengetahuan yang diinginkan. Namun kenyataan yang terjadi di Lapangan tidak sesuai dengan yang di harapkan. Pembelajaran IPA di SD dalam pencapaian kompetensi pengetahuan yang optimal belum dilaksanakan secara maksimal, demikian halnya yang terjadi di SD Gugus Kompyang Sujana Denpasar Utara.

Pendidikan IPA di SD dapat menjadi wahana bagi peserta didik untuk mempelajari diri sendiri dan alam sekitar, serta prospek pengembangan lebih lanjut dalam menerapkannya di dalam kehidupan seharihari. Menurut (GM. Putra Aristyadharma, DB.KT.Semara Putra, 2014) memaparkan bahwa IPA merupakan pembelajaran yang mengandung unsur alam yang tentunya dapat dijumpai dikehidupan sehari hari siswa yang tersebar dalam lingkungan sekitar siswa, untuk itu mata pelajaran IPA wajib disisipkan di kurikulum sekolah dasar. Ilmu Pengetahuan Alam sebagai sebuah mata pelajaran dan dapat diterapkan dalam kehidupan sehari hari, sehingga pendidikan IPA menjadi sangat penting. Pembelajaran ilmu pengetahuan alam di sekolah dasar menekankan pada pemberian pengalaman belajar secara langsung. Menurut (Ketut \& MD, 2014) Pembelajaran IPA yang diajarkan untuk anak SD berbeda dengan pembelajaran IPA untuk ilmuwan, karena struktur kognitif mereka berbeda. Anak SD juga perlu dibekali dengan keterampilanketerampilan proses IPA, karena mereka diharapkan dapat berfikir dan memiliki sikap ilmiah. Maka pembelajaran IPA SD yang menekankan keterampilan proses perlu membangun pengetahuan dalam perkembangannya.

Berdasarkan hasil wawancara dengan guru kelas V SD Gugus Kompyang Sujana Denpasar Utara di Kota Denpasar, kurangnya penerapan model pembelajaran dan media pembelajaran dalam pembelajaran IPA, disebabkan oleh keterbatasan pengetahuan guru tentang model pembelajaran inovatif. Selanjutnya, pada proses pembelajaran IPA guru tidak menggunakan media pembelajaran karena keterbatasan waktu yang dimiliki guru untuk menyiapkan media pembelajaran. Dalam pembelajaran IPA apabila guru lebih mendominasi dalam menjelaskan materi, hal tersebut dapat menimbulkan rasa bosan dan kurang antusiasnya para peserta didik dalam mengikuti pembelajaran di Kelas, alhasil para siswa tidak menerima materi pembelajaran dengan baik dan akan berdampak pada rendahnya kompetensi pengetahuan siswa.

Alternatif yang dipandang mampu meningkatkan kompetensi pengetahuan IPA adalah yaitu penerapan pembelajaran kooperatif, dengan model think pair share. Alasan peneliti memilih alternatif tersebut adalah model think pair share, pembelajaran dimana siswa bekerja dalam kelompok-kelompok kecil saling membantu belajar satu sama lainnya, memberikan waktu kepada para siswa untuk berpikir dan merespon serta saling membantu satu sama lain, memberi siswa kesempatan untuk bekerja sendiri serta bekerja sama dengan teman sebangku sehingga diharapkan kompetensi pengetahuan yang diperoleh semakin bagus. Serta dapat membangkitkan semangat dan meningkatkan kompetensi pengetahuan siswa dalam mata pelajaran IPA yaitu dengan model pembelajaran kooperatif tipe think pair share (TPS). (Huda, 2018) menyatakan TPS memperkenalkan gagasan tentang waktu tunggu atau berpikir 
(wait or think time) pada elemen interaksi ini ampuh dalam meningkatkan respons siswa terhadap pertanyaan.

Menurut (Afandi, Muhammad, 2013) model pembelajaran kooperatif (cooperative learning) adalah suatu kegiatan pembelajaran yang dilaksanakan dengan cara bekerja kelompok untuk bekerjasama saling membantu sama lain setiap anggota kelompok yang terdiri dari 4 sampai 5 orang siswa yang dibuat secara heterogen (kemampuan, gender, suku, ras, karakter). Menurut (Aris, 2014) think pair share adalah suatu model pembelajaran kooperatif yang memberi siswa waktu untuk berpikir dan merespon serta saling bantu sama lain dengan intruksi dari guru. Model pembelajaran think pair share memperkenalkan ide waktu berpikir atau waktu tuggu yang menjadi faktor kuat dalam meningkatkan kemampuan siswa dalam merespon dan memproses pertanyaan. Pembelajaran kooperatif model think pair share ini relatif lebih sederhana karena tidak menyita waktu yang lama untuk mengatur tempat duduk ataupun mengelompokan siswa. Pembelajaran ini melatih siswa untuk berani memberi pendapat dan menghargai pendapat teman. Think pair share memberikan kepada siswa waktu untuk berpikir dan merespon serta saling membantu satu sama lain. Think pair share memiliki prosedur yang memberi siswa waktu untuk berpikir, menjawab, saling membantu satu sama lain. Dengan demikian diharapkan siswa mampu bekerja sama, saling membutuhkan, dan saling bergantung pada kelompok kecil secara kooperatif.

Penelitian yang berkaitan dnegan model ini anatra lain, penelitian ini didukung oleh beberapa hasil penelitian terdahulu. (Ni Putu Ida Handayani1, Made Putra, 2017) menunjukkan bahwa terdapat perbedaan yang signifikan kompetensi pengetahuan IPA kelompok siswa yang dibelajarkan melalui model pembelajaran TPS dengan kelompok siswa yang dibelajarkan melalui model pembelajaran konvensional pada siswa kelas V. Penerapan model pembelajaran think pair share dapat membuat situasi belajar yang lebih baik dan kondusif hal ini dikarenakan pada proses pembelajaran siswa tidak hanya berpikir, menulis, bertanya atau berbicara melaikan melakukan aktivitas fisik yang dapat menimbulkan dan meningkatkan kompetensi pengetahuan IPA. Penelitian yang serupa dilakukan oleh (Raditya et al., 2015) yang menyatakan bahwa penerapan think pair share dapat melatih siswa bekerja dan berinteraksi dalam kelompok baik bertanya, menjawab maupun mengemukakan pendapatnya ketika proses pembelajaran sehingga berdampak positif terhadap kompetensi pengetahuan IPA. Selanjutnya (GM. Putra Aristyadharma, DB.KT.Semara Putra, 2014) menyatakan bahwa penggunaan penilaian kinerja memberikan pengaruh positif karena dalam prosesnya siswa menjadi terlibat secara aktif dalam pembelajaran yang langsung diamati oleh guru sehingga kompetensi pengetahuan IPA siswa menjadi meningkat.

Kata media berasal dari bahasa Latin dan merupakan bentuk jamak dari kata medium yang secara harfiah berarti perantara atau pengantar. Media adalah perantara atau pengantar pesan dari pengirim ke penerima pesan. Menurut Gagne (Sadirman, 2014) media adalah berbagai jenis komponen dalam lingkungan siswa yang dapat merangsangnya untuk belajar. Menurut (Sucianingtyas et al., 2013) "Media TTS merupakan permainan bahasa dengan cara mengisi kotak-kotak dengan huruf-huruf sehingga membentuk kata yang dapat dibaca baik secara vertikal maupun horizontal". Media permainan teka-teki silang (TTS) adalah salah satu media yang dapat digunakan dalam proses kegiatan belajar mengajar dengan menggunakan media permainan ini dapat membuat suasana lingkungan belajar lebih menyenangkan, menambah kosakata baru, dan mampu membuat suasana kelas lebih kondusif. manfaat permainan teka-teki silang adalah permainan yang mengusir kebosanan di kelas, membuat siswa bermain sambil belajar karena teka - teki silang dapat meningkatkan kemampuan mengeja, menambah perbendaharaan kata, problem solving dan dapat melatih otak untuk meningkatkan fungsi kerja otak melalui pertanyaan-pertanyaan yang diberikan berikut pengalaman-pengalaman baru.

Berdasarkan permasalahan tersebut, maka perlu dilakukan penelitan yang berjudul "Pengaruh Model Pembelajaran Think Pair Share Berbantuan Media Permaianan Teka-Teki Silang Terhadap Kompetensi Pengetahuan IPA Siswa Kelas V Di Gugus Kompyang Sujana Kecamatan Denpasar Utara Tahun Ajaran 2018/2019", dengan tujuan untuk mengetahui pengaruh model pembelajaran think pair share berbantuan media permaian teka-teki silang terhadap kompetensi pengetahuan IPA siswa kelas V di gugus kompyang sujana Kecamatan Denpasar Utara.

\section{Metode}

Penelitian ini dilaksanakan pada siswa kelas V SD Gugus Kompyang Sujana Kecamatan Denpasar Utara tahun ajaran 2018/2019 dengan rancangan penelitian yang digunakan adalah rancangan penelitian eksperimen semu (quasi experiment) dengan pola dasar Post Test Only Control Group Design. Dalam rancangan ini pengambilan sampel dilakukan dengan memilih kelas yang akan dijadikan sampel secara random. Populasi dalam penelitian ini adalah semua siswa kelas V di SD Gugus Kompyang Sujanan Kecamatan Denpasar Utara yang terdiri dari 7 SD dengan jumlah seluruh siswa kelas V adalah adalah 255 
siswa. Untuk mengetahui apakah kemampuan siswa kelas V masing-masing SD setara atau tidak, maka terlebih dahulu dilakukan uji kesetaraan dengan menggunakan analisis varians satu jalur (ANAVA A). Berdasarkan hasil analisis diperoleh bahwa HO yang menyatakan tidak terdapat perbedaan yang signifikan pada Kpmpetensi Pengetahuan IPA siswa kelas V di SD Gugus Kompyang Sujana Kecamatan Denpasar Utara diterima.

Teknik pengambilan sampel pada penelitian ini digunakan simple random sampling. Berdasarkan hasil random sampling, diperoleh siswa kelas V SD Negeri 4 Peguyangan yang berjumlah 39 orang siswa sebagai kelas eksperimen dan kelas V SD Negeri 3 Tonja yang berjumlah 35 orang siswa sebagai kelas kontrol.

Pengumpulan data dalam penelitian ini menggunakan metode tes, yaitu tes objektif dalam bentuk pilihan ganda. Tes kompetensi pengetahuan IPA yang digunakan disesuaikan dengan jenjang kemampuan kognitif siswa. Dalam penelitian ini akan dilakukan test pada kelas eksperimen dan kelas kontrol yang disebut dengan post-test. Post-test dilakukan setelah kelas mendapat perlakuan yang berbeda, yaitu kelas experimen pembelajaran dengan menerapkan model pembelajaran think pair share berbantuan media permainan teka-teki silang sedangkan kelas kontrol menggunakan pembelajaran konvensional.

Dalam penelitian ini teknik analisis data yang digunakan yaitu analisis statistik deskriptif dan statistik inferensial (uji-t dengan polled varians) untuk menguji hipotesis penelitian. Data yang diperoleh dalam penelitian ini adalah data kuantitatif dan kualitatif. Data tersebut diolah menggunakan analisis statistik dan analisis non statistik. Data kuantitatif akan dianalisis dengan analisis statistik deskriptif untuk mendeskripsikan data kompetensi pengetahuan IPA siswa. Kemudian data kualitatif dianalisis dengan memberi makna terhadap deskripsi data. Analisis statistik digunakan untuk menggeneralisasi hasil penelitian yang meliputi estimasi (perkiraan), uji prasyarat berupa uji normalitas dan uji homogenitas, serta uji hipotesis.

\section{Hasil dan Pembahasan}

Berdasarkan hasil perhitungan diperoleh analisis data statistik pada Tabel 1.

Tabel 1. Deskripsi Data Kompetensi Pengetahuan IPA Kelompok Eksperimen dan Kelompok Kontro

\begin{tabular}{lrc}
\hline \multicolumn{1}{c}{ Statistik } & Kelompok Eksperimen & Kelompok Kontrol \\
\hline Mean & 82,69 & 73,94 \\
Varians & 83,32 & 111,74 \\
Standar Deviasi & 9,13 & 10,57 \\
\hline
\end{tabular}

Berdasarkan Tabel 1. di atas, diketahui bahwa sebaran data kelompok eksperimen memperoleh mean lebih besar dari mean kelompok kontrol. Dengan demikian, sebaran data kelompok kontrol yang berarti sebagian besar skor cendrung rendah. Sebelum melakukan uji hipotesis maka harus dilakukan beberapa uji prasyarat yaitu uji normalitas dan homogenitas sebaran data. Adapun rumus yang digunakan sebagai berikut.

$$
\frac{(f o-f h)^{2}}{f h}
$$

(Sumber: (Agung, 2014))

Keterangan:

$$
\begin{aligned}
& X^{2}=\sum \\
& X^{2}=\text { Chi-Square } \\
& \text { fo }=\text { frekuensi yang diperoleh } \\
& \text { fh }=\text { frekuensi yang diharapkan }
\end{aligned}
$$


Berdasarkan hasil perhitungan diperoleh analisis data statistik pada tabel 2

Tabel 2. Hasil Uji Normalitas Sebaran Data

\begin{tabular}{clccc}
\hline No & \multicolumn{1}{c}{ Sampel } & $\chi^{2}$ hitung & $\chi^{2}$ tabel & Status \\
\hline 1 & Kelas Eksperimen & 5,44 & 11,07 & Normal \\
2 & Kelas Kontrol & 1,44 & 11,07 & Normal \\
\hline
\end{tabular}

Dari hasil perhitungan dengan menggunakan rumus Chi-Kuadrat, hasil post test kelompok eksperimen hitung sebesar 5,44 pada taraf signifikansi 5\% dengan derajat kebebasan 5 dan diketahui $\chi^{2}$ tabel adalah 11,07, ini berarti bahwa $\chi^{2}$ hit $<\chi^{2}$ tab, maka data hasil post-test siswa kelompok eksperimen berdistribusi normal. Sedangkan Chi kuadrat data hasil post-test kelompok kontrol $\chi^{2}$ hitung adalah 1,44 pada taraf signifikansi 5\% dengan derajat kebebasan 5 dan diketahui $\chi^{2}$ tab $=11,07$, ini berarti bahwa $\chi^{2}$ hit $<\chi^{2}$ tab maka data hasil post-test kelompok kontrol berdistribusi normal. Berdasarkan data hasil post-test kelompok eksperimen maupun kelompok kontrol berdistribusi normal. Setelah melakukan uji prasyarat yang pertama yaitu uji normalitas, selanjutnya dilakukan uji prasyarat yang ke dua yaitu uji homogenitas. Uji homogenitas varians dilakukan terhadap varians pasangan antar kelompok eksperimen dan kontrol. Uji yang digunakan adalah uji-F dengan kriteria data homogen jika $F_{\text {hitung }}<F_{\text {tabel. }}$ Rangkuman hasil uji homogenitas varians antar kelompok eksperimen dan kontrol disajikan pada Tabel 3.

Tabel 3. Hasil Uji Homogenitas Varians

\begin{tabular}{llll}
\hline \multicolumn{1}{c}{ Sumber Data } & Fhitung & $\mathbf{F t a b e l}_{\mathbf{5} \%}$ & Keterangan \\
\hline $\begin{array}{l}\text { Post-test kelompok eksperimen dan kelompok } \\
\text { kontrol }\end{array}$ & 1,34 & 1,74 & Homogen \\
\hline
\end{tabular}

Berdasarkan Tabel di atas, diketahui harga $F_{\text {hitung }}$ sebesar 1,34. Sedangkan $F_{\text {tabel }} 1,74$ pada taraf signifikan 5 \% dengan derajat kebebasan pembilang 39-1 = 38 dan derajat kebebasan penyebut 35-1=34.

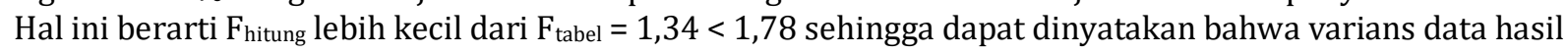
post test kelompok eksperimen dan kontrol adalah homogen.

Setelah diperoleh hasil dari uji prasyarat analisis, maka dilanjutkan dengan pengujian hipotesis alternatif ( $\mathrm{Ha}$ ) yang berbunyi "terdapat perbedaan yang signifikan kompetensi pengetahuan IPA antara siswa yang mengikuti pembelajaran dengan menggunakan model pembelajaran think pair share berbantuan media permainan teka-teki silang dengan siswa yang mengikuti pembelajaran dengan menggunakan model pembelajaran konvensional pada siswa kelas V di SDN Gugus Kompyang Sujana Kecamatan Denpasar Utara". Namun dalam perhitungan statistik digunakan hipotesis nol (H0).

Setelah dilakukan analisi uji prasyarat, diperoleh bahwa data hasil posttest kelompok eksperimen dan kelompok kontrol berdistribusi normal dan memiliki varians yang homogen. Jumlah sampel kelompok eksperimen sama dengan jumlah sampel kelompok kontrol (n1 $\neq n 2$ ). Oleh karena itu, dalam uji hipotesis dapat digunakan rumus t-test untuk penelitian empiris. Kriteria pengujian adalah $\mathrm{HO}$ ditolak jika thitung $>$ ttabel. Rangkuman hasil uji-t antar kelompok eksperimen dan kontrol disajikan pada Tabel 4.

Tabel 4. Ringkasan Hasil Uji-t Kelompok Eksperimen dan Kelompok Kontrol

\begin{tabular}{lcccccc}
\hline \multicolumn{1}{c}{ Kompetensi Pengetahuan IPA } & $\mathbf{N}$ & $\mathbf{D b}$ & Mean & $\mathbf{S}^{\mathbf{2}}$ & $\mathbf{t}_{\text {hitung }}$ & $\mathbf{t}_{\text {tabel }}$ \\
\hline Eksperimen & 39 & 72 & 82,69 & 83,32 & 3,82 & 2.000 \\
Kontrol & 35 & & 73,94 & 111,74 & & \\
\hline
\end{tabular}

Hasil perhitungan uji-t dengan polled varians, diperoleh thitung sebesar 3,82. Sedangkan tabel dengan $\mathrm{db}=72$ pada taraf signifikansi $5 \%$ adalah 2,000. Hal ini berarti $t_{\text {hitung }}$ lebih besar dari $t_{\text {tabel }}(3,82>2,000)$ sehingga $\mathrm{H}_{0}$ ditolak dan $\mathrm{H}_{a}$ diterima. Dengan demikian, dapat diinterpretasikan bahwa terdapat perbedaan yang signifikan kompetensi pengetahuan IPA antara siswa yang mengikuti pembelajaran dengan menggunakan model think pair share berbantuan media permainan teka-teki silang pada siswa kelas V di Gugus Kompyang Sujana Kecamatan Denpasar Utara.

Berdasarkan uraian hasil penelitian ini, dapat dikemukakan bahwa model think pair share berbantuan media permainan teka-teki silang pada siswa kelas V di Gugus Kompyang Sujana Kecamatan Denpasar Utara. Peningkatan ini terjadi karena dalam pembelajaran menggunakan model think pair share berbantuan berbantuan media permainan teka-teki silang mampu menciptakan suasana belajar yang 
lebih menarik dan menyenangkan bagi siswa. Dalam pembelajarannya siswa dapat merasakan belajar seperti bermain, hal ini sesuai dengan karakteristik anak usia sekolah dasar yang masih gemar bermain sehingga sangat tepat diterapkan dan tidak akan membuat kejenuhan siswa dalam belajar. Suasana yang menyenangkan akan menciptakan proses belajar yang lebih bermakna secara afektif atau emosional bagi siswa. Model think pair share, pembelajaran dimana siswa bekerja dalam kelompok-kelompok kecil saling membantu belajar satu sama lainnya, memberikan waktu kepada para siswa untuk berpikir dan merespon serta saling membantu satu sama lain, memberi siswa kesempatan untuk bekerja sendiri serta bekerja sama dengan teman sebangku sehingga diharapkan kompetensi pengetahuan yang diperoleh semakin bagus. Serta dapat membangkitkan semangat dan meningkatkan kompetensi pengetahuan siswa dalam mata pelajaran IPA yaitu dengan model pembelajaran kooperatif tipe think pair share (TPS). (Huda, 2018) menyatakan TPS memperkenalkan gagasan tentang waktu tunggu atau berpikir (wait or think time) pada elemen interaksi ini ampuh dalam meningkatkan respons siswa terhadap pertanyaan.

Model pembelajaran think pair share berbantuan berbantuan media permainan teka-teki silang yang diterapkan pada kelompok eksperimen dan model konvensional yang diterapkan pada kelompok kontrol dalam penelitian ini menunjukkan pengaruh yang berbeda terhadap kompetensi pengetahuan IPA siswa. Secara deskriptif kompetensi pengetahuan IPA siswa kelompok siswa yang mengikuti pembelajaran dengan model think pair share berbantuan berbantuan media permainan teka-teki silang menunjukkan hasil yang lebih tinggi dibandingkan dengan kelompok siswa yang mengikuti pembelajaran dengan model konvensional. Pada kelompok eksperimen, kegiatan pembelajaran pada muatan materi IPA menerapkan model pembelajaran think pair share berbantuan media permaianan teka-teki silang dapat membuat siswa lebih aktif dalam mengikuti pembelajaran. Bukan hanya karena model yang digunkan. Media juga memepunyai adil yang besar dalam pproses pembelajaran. Menurut Gagne (Sadirman, 2014) media adalah berbagai jenis komponen dalam lingkungan siswa yang dapat merangsangnya untuk belajar. Menurut (Sucianingtyas et al., 2013) "Media TTS merupakan permainan bahasa dengan cara mengisi kotak-kotak dengan huruf-huruf sehingga membentuk kata yang dapat dibaca baik secara vertikal maupun horizontal". Media permainan teka-teki silang (TTS) adalah salah satu media yang dapat digunakan dalam proses kegiatan belajar mengajar dengan menggunakan media permainan ini dapat membuat suasana lingkungan belajar lebih menyenangkan, menambah kosakata baru, dan mampu membuat suasana kelas lebih kondusif. manfaat permainan teka-teki silang adalah permainan yang mengusir kebosanan di kelas, membuat siswa bermain sambil belajar karena teka - teki silang dapat meningkatkan kemampuan mengeja, menambah perbendaharaan kata, problem solving dan dapat melatih otak untuk meningkatkan fungsi kerja otak melalui pertanyaan-pertanyaan yang diberikan berikut pengalaman-pengalaman baru.

Menurut (Aribowo, 2014) keunggulan dari media permainan teka-teki silang adalah sebagai berikut. 1. Mengusir kebosanan, mengerjakan teka-teki silang merupakan suatu aktivitas yang menyenangkan. Teka-teki silang dapat merangsang siswa untuk berpikir kritis dan kreatif sehingga mereka merasa tertantang untuk menyelesaikan teka-teki silang tersebut. 2. Menambah perbendaharaan kosakata, pemecahan teka-teki silang melibatkan beberapa keterampilan termasuk kosakata dan penalaran. Untuk menjawab teka-teki silang, seseorang harus mampu mengidentifikasi dan memahami istilah-istilah yang digunakan. Hal ini sering kali melibatkan siswa dalam memperoleh kosakata baru. 3 . Meningkatkan kemampuan mengeja, jawaban pada teka-teki silang terbatas pada kosakata tertentu yang dibubuhkan pada kotak dengan jumlah tertentu. Jawaban yang tepat menuntut ketelitian dan kejelian dalam hal ejaan karena apabila terdapat kesalahan fonem yang keliru, maka akan berpengaruh pada kotak jawaban lain, 4. Mengajarkan problem solving, teka-teki silang juga dapat dianggap sebagai sejenis permainan intelektual linguistik yang dalam beberapa cara mirip dengan perdebatan verbal. Mengisi tekateki silang biasanya dilakukan dengan soal yang lebih mudah terlebih dahulu karena jawaban tersebut dapat sebagai alat bantu dalam menjawab pertanyaan lain yang bersinggungan dalam kotak yang sama. Ini sejalan dengan pendapat menurut (Sucianingtyas et al., 2013) "Media TTS merupakan permainan bahasa dengan cara mengisi kotak-kotak dengan huruf-huruf sehingga membentuk kata yang dapat dibaca baik secara vertikal maupun horizontal". Media permainan teka-teki silang (TTS) adalah salah satu media yang dapat digunakan dalam proses kegiatan belajar mengajar dengan menggunakan media permainan ini dapat membuat suasana lingkungan belajar lebih menyenangkan, menambah kosakata baru, dan mampu membuat suasana kelas lebih kondusif.

Berbeda halnya dengan pembelajaran IPA di kelompok kontrol yang menggunakan pembelajaran konvensional. Hal ini disebabkan oleh perlakuan pada langkah-langkah pembelajaran. Dalam pembelajaran metode konvensional ditandai dengan ceramah serta pembagian tugas dan latihan. Kegiatan pembelajaran lebih banyak didominasi oleh guru (Teacher Center) sehingga kegiatan siswa lebih banyak hanya mendengar dan mencatat. Siswa dalam mengikuti pembelajaran terkesan tidak terlalu 
semangat dan aktif dalam menjawab atau mengemukakan pendapatnya meskipun sudah ditunjuk oleh guru. Dalam kegiatan kelompok, siswa kurang melakukan interaksi satu sama lain karena tugas atau permasalah diselesaikan oleh siswa yang cenderung memiliki kemampuan yang lebih pintar dari siswa lain dalam kelompoknya. Dengan pembelajaran seperti ini, siswa akan mengingat materi dengan hafalan yang mana siswa akan merasa bosan dan jenuh selain itu siswa menjadi kurang mampu mengembangkan kemampuannya masing-masing. Hal inilah yang menyebabkan kompetensi kemampuan IPA siswa pada kelompok yang dibelajarkan dengan pembelajaran konvensional cenderung rendah.

Perbedaan cara pembelajaran antara kelompok siswa yang dibelajarkan dengan model pembelajaran think pair share berbantuan media permaian teka-teki silang dengan pembelajaran konvensional tentunya memberikan dampak yang berbeda pula terhadap hasil belajar siswa. Temuan dalam penelitian ini didukung oleh beberapa hasil penelitian terdahulu. (Ni Putu Ida Handayani1, Made Putra, 2017) menunjukkan bahwa terdapat perbedaan yang signifikan kompetensi pengetahuan IPA kelompok siswa yang dibelajarkan melalui model pembelajaran TPS dengan kelompok siswa yang dibelajarkan melalui model pembelajaran konvensional pada siswa kelas V. Penerapan model pembelajaran think pair share dapat membuat situasi belajar yang lebih baik dan kondusif hal ini dikarenakan pada proses pembelajaran siswa tidak hanya berpikir, menulis, bertanya atau berbicara melaikan melakukan aktivitas fisik yang dapat menimbulkan dan meningkatkan kompetensi pengetahuan IPA. Penelitian yang serupa dilakukan oleh (Raditya et al., 2015) yang menyatakan bahwa penerapan think pair share dapat melatih siswa bekerja dan berinteraksi dalam kelompok baik bertanya, menjawab maupun mengemukakan pendapatnya ketika proses pembelajaran sehingga berdampak positif terhadap kompetensi pengetahuan IPA. Selanjutnya (GM. Putra Aristyadharma, DB.KT.Semara Putra, 2014) menyatakan bahwa penggunaan penilaian kinerja memberikan pengaruh positif karena dalam prosesnya siswa menjadi terlibat secara aktif dalam pembelajaran yang langsung diamati oleh guru sehingga kompetensi pengetahuan IPA siswa menjadi meningkat.

Dengan demikian dapat dinyatakan bahwa model pembelajaran model pembelajaran think pair share berbantuan media permaian teka-teki silang berpengaruh lebih besar terhadap kompetensi pengetahuan IPA dari pada kelompok siswa yang dibelajarkan dengan pembelajaran konvensional pada muatan IPA, siswa kelasIV di SD Gugus Kompyang Sujana Kecamatan Denpasar Utara Tahun Ajaran 2018/2019.

Perbedaan yang terjadi pada kompetensi pengetahuan IPA ini terjadi karena dalam pembelajaran menggunakan model think pair share berbantuan media permaian teka-teki silang mampu menciptakan suasana belajar yang lebih menarik dan menyenangkan bagi peserta didik. Dalam pembelajarannya siswa dapat merasakan belajar seperti bermain, hal ini sesuai dengan karakteristik anak usia sekolah dasar yang masih gemar bermain sehingga sangat tepat diterapkan dan tidak akan membuat kejenuhan siswa dalam belajar. Suasana yang menyenangkan akan menciptakan proses belajar yang lebih bermakna secara afektif atau emosional bagi siswa.

Model pembelajaran think pair share berbantuan media permaianan yang diterapkan pada kelompok eksperimen dalam penelitian ini menunjukkan pengaruh yang berbeda terhadap kompetensi pengetahuan IPA siswa. Secara deskriptif kompetensi pengetahuan IPA siswa kelompok siswa yang mengikuti pembelajaran dengan think pair share berbantuan media permaianan teka-teki silang menunjukkan hasil yang lebih tinggi dibandingkan dengan kelompok siswa yang mengikuti pembelajaran dengan model konvensional. Rata-rata skor kompetensi pengetahuan IPA pada kelompok eskperimen adalah 82,69 sedangkan pada kelas kontrol rata-rata skor kompetensi pengetahuan IPA adalah 73,94. Selain dilihat dari rata-rata nilai tersebut, perbedaan antara kelompok siswa yang dibelajarkan dengan model think pair share berbantuan media permaiana teka-teki silang dan siswa yang dibelajarkan dengan model konvensional juga dapat dilihat dari hasil uji t yang dilakukan. Berdasarkan hasil berhitungan uji $\mathrm{t}$ diperoleh thitung sebesar 3,82 dan tabel sebesar 2,000. Hal ini terdapat pengaruh yang signifikan kompetensi pengetahuan IPA antara kelompok siswa yang dibelajarkan dengan model think pair share berbantuan media permaianan teka-teki silang dan siswa yang dibelajarkan dengan model konvensional pada siswa kelas V SD di Gugus Kompyang Sujana Kecamatan Denpasar Utara.

Pada kelompok eksperimen, kegiatan pembelajaran pada muatan materi IPA menerapkan model pembelajaran think pair share berbantuan meida permaianan teka-teki silang dapat membuat siswa lebih aktif dalam mengikuti pembelajaran. Hal ini dikarenakan penerapan model pembelajaran think pair share berbantuan media permaianan teka -teki silang. Penggunaan model pembelajaran think pair share merupakan strategi yang cocok digunakan untuk mengatasi masalah-masalah dalam pembelajaran IPA selain itu pemilihan media permainan teka-teki silang dapat membantu guru untuk memberikan penilaian yang lebih otentik karena dapat langsung diamati dari kinerja siswa selama mengikuti pembelajaran. Dengan model pembelajaran ini, akan tercipta diskusi kelompok dan interaksi siswa dari kelompok yang berbeda yang memungkinkan terjadinya saling sharing pengetahuan dan pengalaman dalam upaya 
menyelesaikan permasalahan yang ada. Selain itu model pembelajaran think pair share berbantuan media permainan teka-teki silang ini mampu melatih siswa untuk lebih tanggap dan mampu berpikir kritis dalam menerima dan menyampaikan pesan.

\section{Simpulan dan Saran}

Berdasarkan hasil penelitian yang telah dilaksanakan, dapat ditarik kesimpulan sebagai berikut. (1) Kompetensi Pengetahuan IPA kelas V di Gugus Kompyang Suajana Kecamatan Denpasar Utara Tahun Ajaran 2018/2019 siswa yang mengikuti pembelajaran dengan model pembelajaran Think Pair Share berbantuan media permainan teka-teki silang pada kelompok eksperimen memiliki nilai rata-rata sebesar 82,69 yang termasuk pada kriteria sangat tinggi. (2) Kompetensi Pengetahuan IPA kelas V di Gugus Kompyang Suajana Kecamatan Denpasar Utara tahun ajaran 2018/2019 siswa yang mengikuti pembelajaran konvensional pada kelompok kontrol memiliki nilai rata-rata sebesar 73,94 yang termasuk pada kriteria sedang. (3) Hasil hipotesis menunjukkan bahwa terdapat perbedaan yang singnifikan kompetensi pengetahuan IPA antara siswa yang mengikuti pembelajaran dengan model pembelajaran think pair share berbantuan media permainan teka-teki silang dan siswa yang mengikuti pembelajaran konvensional. Hal ini didukung dengan nilai rata-rata siswa kelompok eksperimen $=82,69$ yang termasuk pada kriteria sangat tinggi dan nilai rata-rata siswa kelompok kontrol $=73,94$ yang termasuk pada kriteria sedang. Selanjutnya data tersebut diperkuat lagi dengan hasil analisis uji-t yang menunjukkan nilai thitung lebih besar dari tabel $(3,82>2,000)$. Adanya perbedaan yang signifikan menunjukkan bahwa penerapan model pembelajaran think pair share berbantuan media permainan teka-teki silang berpengaruh positif terhadap kompetensi pengetahuan IPA siswa kelas V di SDN 4 Peguyangan.

Beberapa saran yang dapat disampaikan berdasarkan penelitian yang telah dilakukan adalah sebagai berikut. (1) Siswa agar siswa lebih banyak lagi melatih kemampuan berpikir kritisnya, merumuskan pertanyaan dan mengemukakan pendapat melalui pembelajaran yang menerapkan model pembelajaran think pair share berbantuan media permainan teka-teki silang guna mengatasi permasalahan pada kompetensi pengetauan IPA. (2) Guru hendaknya lebih berinovasi dalam pengelolaan pembelajaran dengan menggunakan model-model pembelajaran inovatif yang dapat menciptakan suasana belajar yang menyenangkan sehingga dapat meningkatkan kompetensi pengetahuan siswa. (3) Sekolah yang mengalami permasalahan rendahnya kompetensi pengetahuan IPA, dapat menerapkan model pembelajaran think pair share berbantuan media permaianan teka-teki silang dalam pembelajaran guna mengatasi permasalahan tersebut. (4) Jika ingin menerapkan model pembelajaran model pembelajaran think pair share berbantuan media permaianan teka-teki silang dalam pembelajaran IPA diharapkan mencermati kendala - kendala yang ditemukan peneliti, sehingga dapat dihasilkan kegiatan pembelajaran yang dapat meningkatkan kompetensi pengetahuan siswa secara optimal.

\section{Daftar Rujukan}

Abdilah, A. \&. (2018). Pembelajaran Terpadu : Karakter, Landasan, Fungsi Prinsip Dan Model. Lembaga Peduli Pengembangan Pendidikan Indonesia (LPPPI).

Afandi, Muhammad, dkk. (2013). Model dan Metode Pembelajaran di Sekolah. Sultan Agung Press.

Agung, A. A. G. (2014). Metodologi Penelitian Pendidikan. Aditya Media Publish.

Aribowo, E. K. (2014). Media Pembelajaran DIY: Membuat Flash Card dan Teka-Teki Silang Mandiri. Pembelajaran Bahasa Untuk Meningkatkan Kualitas Manusia Indonesia Yang Berkarakter Dalam Era Mondial, 1(July), 140-150. https://doi.org/10.6084/m9.figshare.6444407

Aris, S. (2014). Model pembelajaran Inovatif Dalam Kurikulum 2013. In 1 (Issue). Yogyakarta: AR-ruz media.

GM. Putra Aristyadharma, DB.KT.Semara Putra, I. M. A. (2014). Pengaruh Model Pembelajaran NHT Berbantuan Media Kongkret Terhadap Hasil Belajar Ipa Siswa Kelas V Gugus I Kuta, Badung Tahun Ajaran 2013/2014 gm. E-Jurnal Mimbar PGSD Universitas Pendidikan Ganesha, 2(1).

Huda, M. (2018). Model-Model Pengpelajaran dan Pembelajaran Isu-Isu Metodis dan Paradigmatis. Pustaka Pelajar.

I Made Yudha Pranata, I Wayan Suwatra, M. S. (2017). Pengaruh Model PBL Berbantuan Media Gambar terhadap Hasil Belajar IPA pada Siswa Kelas V. MIMBAR PGSD Undiksha, 5(2). https://doi.org/10.23887/jjpgsd.v5i2.11005 
Ketut, S., \& MD, S. I. (2014). Peningkatan Hasil Belajar Siswa Menggunakan Metode Problem Soving Dalam Pembelajaran IPA. Learning, 1(2), 75-82.

Ni Putu Ida Handayani1, Made Putra, I. K. A. (2017). PENGARUH MODEL PEMBELAJARAN THINK TALK WRITE BERBASIS TRI HITA KARANA TERHADAP KOMPETENSI PENGETAHUAN IPS Jurusan Pendidikan Guru Sekolah Dasar , FIP Universitas Pendidikan Ganesha. Mimbar PGSD, 5(2), 1-10.

Raditya, I. W., Kristiantari, M. R., \& Suara, D. I. M. (2015). Pengaruh model pembelajaran kooperatif tipe think pair share (TPS) terhadap hasil belajar IPA siswa kelas VI SD Gugus Letda Made Putra Kecamatan Denpasar Utara tahun ajaran 2014/2015. E-Journal PGSD Universitas Pendidikan Ganesha, 3, 1-10.

Sadirman. (2014). . Interaksi dan Motivasi Belajar Mengajar. Rajawali Pers.

Salahuddin, Akos, M., \& Hermawan, A. (2018). Meningkatkan Mutu Pendidikan Melalui Sumber Daya Manusia Dan Sarana Prasarana Di Mtsn Banjar Selatan 2 Kota Banjarmasin. Jurnal Ilmu Administrasi Dan Manajemen, 2(1), 1-13.

Samatowa, U. (2010). Pembelajaran IPA di Sekolah Dasar. PT Indeks.

Sari, Z. O., \& Septiasari, E. A. (2016). Pendidikan Olahraga, Kreativitas, Komunikasi . JJurnal Olahraga Prestasi, 97-110.

Sucianingtyas, R., Sugiharto, S., \& Utomo, S. (2013). Studi Komparasi Penggunaan Media Teka-Teki Silang (Tts) Dengan Kartu Pada Pembelajaran Kimia Melalui Pendekatan Contextual Teaching and Learning (Ctl) Terhadap Prestasi Belajar Siswa Pada Materi Zat Adiktif Dan Psikotropika Kelas Viii Smp N 2 Ngadirojo. Jurnal Pendidikan Kimia Universitas Sebelas Maret, 2(3), 68-76. 